\title{
Analysis of David Kolb's Learning Style According to Mathematical Representation Ability
}

\author{
Umi Hajaro $^{1}$, Akhmad Nayazik ${ }^{2 *}$, Ratih Kusumawati ${ }^{3}$ \\ 1,2,3 Universitas Ivet \\ *ahmadnayazik@gmail.com
}

Received: June 2021. Accepted: July 2021. Published: July 2021.

\begin{abstract}
The purpose of this study was to describe David Kolb's learning style according to the mathematical representation of students. This research is qualitative. The subjects of this study were students of class VIII SMP Agus Salim Semarang. The data were obtained by using the test method of the mathematical representation ability instrument, questionnaire of KLSI (Kolb Learning Style Inventory), interviews, and documentation. The results of this study are: (1). Students with High Mathematical Representation Ability tend to have an assimilator type of learning style, (2). Students with Medium Mathematical Representation Ability tend to have a converger learning style type, and (3). Students with Low Mathematical Representation Ability tend to have a divergent learning style. Teachers are suggested to identify students' learning styles to be the best teachers for students. It is also recommended to collect mathematical representation-based problems to improve students' mathematical representation skills.

Keywords: David Kolb, Mathematics Representation, Assimilator, Converger, Diverger
\end{abstract}

How to Cite: Hajaro, U., Nayazik, A., \& Kusumawati, R. (2021). Analysis of David Kolb's Learning Style According to Mathematical Representation Ability. Journal of Medives: Journal of Mathematics Education IKIP Veteran Semarang, 5(2), 403-416. 


\section{PENDAHULUAN}

Peraturan Menteri Pendidikan dan Kebudayaan No. 58 Tahun 2014, menyatakan bahwa tujuan dari pembelajaran matematika yaitu siswa diharapkan memiliki kemampuan representasi. Hal ini sesuai dengan standar pembelajaran matematika yang ditetapkan oleh NCTM (Martin, 2000) menyatakan bahwa, salah satu kemampuan yang perlu dikuasai dan dikembangkan oleh siswa yaitu kemampuan representasi. Menurut NCTM, representasi didefinisikan sebagai suatu hal yang dilakukan dan dihasilkan dari pencapaian pemahaman konsep matematika dalam berbagai bentuk. Kemampuan ini sangat penting bagi siswa dan erat kaitannya dengan kemampuan komunikasi dan pemecahan masalah. Untuk mengkomunikasikan sesuatu, seseorang perlu representasi baik berupa gambar, grafik, diagram, maupun bentuk representasi lainnya. Sejalan dengan pendapat Li dalam Zhe (2012) "The structure of language in mathematical activities includes external communication such as written and oral representation of symbol, word, graphics, and images". Karena representasi matematis sangat penting, perlu diidentifikasi gaya belajar apa yang dimiliki oleh siswa. Di mana telah diketahui bahwa setiap orang memiliki gaya belajar berbeda-beda sesuai dengan kecenderungan yang dimiliki.

Menurut Hudojo (2002) menyatakan bahwa tidak ada dua individu yang persis sama, setiap individu adalah unik. Suharyanto (1998) menyatakan bahwa jika perbedaan individu kurang diperhatikan, maka banyak siswa akan mengalami kesulitan belajar dan kegagalan belajar. Kenyataan keberhasil- an seorang siswa dalam mencapai prestasi belajarnya sangat dipengaruhi oleh beragam faktor, salah satu faktor yang mempengaruhinya adalah cara belajar siswa, atau yang biasa dikenal dengan gaya belajar. Cara belajar merupakan ciri khas yang dimiliki oleh setiap individu dalam mengolah informasi yang didapatkan. Cara belajar setiap individu cenderung berbeda-beda dengan keunikan masing-masing. Keefe mengungkapkan bahwa penelitian tentang gaya belajar telah dimulai sejak 1892 (Keefe, 1979). Kolb dan Kolb mengidentifikasi bahswa gaya belajar menjadi satu faktor pokok di dalam mendapatkan efektifitas belajar (D. Kolb, 1984)

Menurut Nasution, gaya belajar pada siswa dapat digolongkan berdasarkan kategori-kategori tertentu, pertama, tiap murid belajar menurut cara sendiri yang kita sebut gaya belajar, begitu juga guru mempunyai gaya mengajar masingmasing. Kedua, kita dapat menemukan gaya belajar anak dengan menggunakan instrumen tertentu. Ketiga, kesesuaian gaya mengajar dengan gaya belajar akan mempertinggi efektivitas belajar anak (Nasution, 2000). Salah satunya yaitu gaya belajar oleh David Kolb yang lebih dikenal dengan gaya belajar model Kolb. Gaya belajar model Kolb dipilih dan digunakan oleh seseorang dalam menerima informasi dari lingkungannya dan memproses informasi, karena gaya belajar model ini lebih menekankan polapola perilaku atau sikap seseorang dalam menerima dan memproses informasi dari lingkungan, peneliti ingin menjadikan gaya belajar David Kolb sebagai instrumen yang ingin diteliti. 
A. Y. Kolb \& Kolb, (2005) membagi gaya belajar menjadi empat yaitu: (1) Diverger kombinasi elemen Pengalaman Konkrit dan Observasi Reflektif. Individu dengan gaya belajar ini mampu melihat situasi konkrit dari beragam perspektif; (2) Assimilator kombinasi Konseptualisasi Abstrak dan Observasi Reflektif. Individu ini terampil dalam mengolah banyak informasi serta menempatkannya ke dalam bentuk yang pasti dan logis; (3) Converger kombinasi Konseptualisasi Abstrak dan Ekperimen Aktif. Individu ini paling baik dalam menemukan kegunaan praktis dari ide dan teori; dan (4) Accommodator kombinasi Pengalaman Konkrit dan Eksperimentasi Aktif. Individu ini memiliki keunggulan untuk belajar dari pengalaman langsung.

Murfi \& Rosidah (2016) menyatakan bahwa siswa berprestasi di SMA N 1 Yogyakarta yang mendominasi adalah gaya belajar Assimilator, sedangkan siswa MAN 1 Yogyakarta lebih mendominasi pada gaya belajar Accommodator. Penelitian ini mengambil sampel dari nilai anak berprestasi dikelas lalu diberikan angket gaya belajar David Kolb sebagai instumen nya. Jadi, penelitian ini hanya sebatas mengkomparasikan gaya belajar siswa yang berprestasi saja. Tidak ada perlakuan lebih. Penelitian selanjutnya dilakukan oleh Santosa, (2017) yang menyatakan bahwa Siswa dengan gaya belajar visual mampu memenuhi 2 indikator kemampuan representasi matematis yaitu menyajikan masalah dalam bentuk grafik, tabel, gambar, diagram atau sebaliknya dan menyajikan langkah penyelesaian masalah secara runtun. Siswa dengan gaya belajar auditori mampu memenuhi 2 indikator kemampuan representasi matematis yaitu menyajikan masalah dalam bentuk grafik, tabel, gambar, diagram atau sebaliknya dan menyajikan langkah penyelesaian masalah secara runtun. Siswa dengan gaya belajar kinestetik mampu memenuhi 3 indikator kemampuan representasi matematis yaitu menyatakan peristiwa sehari-hari dalam bentuk simbol matematis, menyajikan masalah dalam bentuk grafik, tabel, gambar, diagram atau sebaliknya dan menyajikan langkah penyelesaian masalah secara runtun. Hal yang membedakan dari penelitian yang dilakukan oleh peneliti adalah penelitian ini mendeskripikan kemampuan representasi yang ditinjau dari gaya belajar, sedangkan penelitian yang dilakukan oleh peneliti yang di deskripsikan merupakan gaya belajar David Kolb menurut kemampuan representasi matematisnya.

Penelitian ini dilakukan berkaitan dengan analisis gaya belajar David Kolb dalam representasi matematis siswa dikelas VIII yang memiliki empat kuadran yakni, gaya Diverger, Assimilator, Converger, dan Accommodator. Penelitian ini dilakukan pada siswa jenjang SMP kelas VIII karena berada dalam tahap formal operasional pada usia ini individu mulai dapat mengatasi masalah keterbatasan pemikiran, dengan kata lain individu telah memiliki kemampuan mengkoordinasikan dengan baik terhadap kemampuan kognitifnya (Syah, 2016)

Dengan menggunakan analisis model gaya belajar David Kolb, akan diketahui perbedaan cara atau metode gaya belajar masing-masing siswa yang memiliki representasi matematis tinggi, sedang dan rendah. Seperti yang telah 
dijelaskan sebelumnya bahwa salah satu keberhasilan siswa dalam pendidikan dapat ditunjukkan dengan nilai terbaik di bidang akademik, namun pada kenyataannya yang telah terjadi saat ini adalah semakin tingginya tuntutan siswa untuk meningkatkan nilai akademik, sementara proses belajar atau gaya belajar yang dimiliki siswa masih belum melakukan inovasi dan elaborasi.

Anggapan bahwa ketika mereka mengajarkan bahan yang sama dengan metode yang sama serta cara penilaian yang sama terhadap semua siswa, maka hasil yang diperoleh oleh siswa adalah sama atau seimbang. Hal ini lah yang kurang tepat dijadikan sebuah asumsi dalam kegiatan belajar siswa. Sebab meskipun semua itu diperlakukan sama, perlu diingat bahwa yang melakukan kegiatan belajar tersebut adalah individu masing-masing, sedangkan kepribadian, minat dan emosional setiap siswa itu berbeda-beda. Oleh karena itu, dengan pembelajaran yang lebih menghargai terhadap perbedaan individu akan lebih mengembangkan siswa sesuai dengan kemampuan dan potensi yang dimilikinya tanpa harus disamakan dengan yang lainnya (Nur \& Risnawita, 2014).
Menurut Murfi \& Rosidah (2016), individu yang tidak mengetahui dan memahami gaya belajarnya sendiri akan lebih sulit dalam menyesuaikan kenyamanan beraktivitas belajar, karena masih labilnya dalam cara mengolah informasi yang didapatkan. Individu yang belajar dengan gaya belajarnya masingmasing lebih banyak memiliki kesempatan dalam meningkatkan prestasi belajarnya, khususnya dalam bidang akademik.

\section{METODE PENELITIAN}

Penelitian ini merupakan jenis penelitian kualitatif. Mekanisme kerja penelitian yang mengandalkan uraian deskriptif kata atau kalimat yang disusun secara cermat dan sistematis tentang gambaran kondisi dari masing-masing bentuk gaya belajar David Kolb yang dimiliki siswa dalam kemampuan merepresentasi matematis.

Penelitian ini menggunakan metode triangulasi melalui tes uraian, dokumetasi, dan wawancara. Tes uraian yang dipergunakan terdiri dari enam permasalahan mengenai teorema phytagoras dan lingkaran. Setiap permasalahan yang diberikan akan mendorong siswa untuk menunjukkan kemampuan representasi-

Tabel 1. Kisi-Kisi Instrumen Tes Kemampuan Representasi Matematis

\begin{tabular}{|c|c|c|c|c|}
\hline No. & $\begin{array}{l}\text { Aspek Kemampuan } \\
\text { Representasi } \\
\text { Matematis } \\
\end{array}$ & Indikator Soal & $\begin{array}{c}\text { No. Butir } \\
\text { Soal }\end{array}$ & $\begin{array}{l}\text { Jumlah } \\
\text { Butir } \\
\text { Soal } \\
\end{array}$ \\
\hline 1. & Gambar (Pictorial) & $\begin{array}{l}\text { Menyelesaikan teorema Phytagoras dan lingkaran } \\
\text { dengan metode grafik dan gambar. }\end{array}$ & 1,2 & 2 \\
\hline & Simbol (Symbolic) & $\begin{array}{l}\text { Menyelesaikan model matematika yang telah dibuat } \\
\text { dari masalah yang berkaitan dengan teorema } \\
\text { Phytagoras dan lingkaran. }\end{array}$ & 3,4 & 2 \\
\hline & Verbal (Verbal) & $\begin{array}{l}\text { Menyelesaikan permasalahan yang berkaitan dengan } \\
\text { teorema Phytagoras dan lingkaran dengan } \\
\text { menggunakan kata-kata dan penafsirannya. } \\
\text { Jumlah Butir Soal }\end{array}$ & 5,6 & 2 \\
\hline
\end{tabular}


Tabel 2. Pedoman Penskoran Instrumen Tes Kemampuan Representasi Matematis Siswa

\begin{tabular}{|c|c|c|}
\hline Aspek & Skor & Uraian \\
\hline Representasi Gambar & 3 & Membuat gambar secara lengkap dan benar \\
\hline \multirow[t]{3}{*}{$\begin{array}{l}\text { (Pictorial } \\
\text { Representation) }\end{array}$} & 2 & $\begin{array}{l}\text { Membuat gambar secara lengkap namun masih ada } \\
\text { kesalahan }\end{array}$ \\
\hline & 1 & $\begin{array}{l}\text { Membuat gambar namun tidak lengkap atau tidak } \\
\text { membuat gambar }\end{array}$ \\
\hline & 0 & $\begin{array}{l}\text { Tidak memberikan jawaban atau memperlihatkan } \\
\text { ketidakpahaman terhadap konsep }\end{array}$ \\
\hline Representasi Kata- kata & 3 & Menulis penjelasan secara logis, benar, dan lengkap \\
\hline (Verbal Representation) & 2 & $\begin{array}{l}\text { Menulis penjelasan secara logis, benar, namun tidak } \\
\text { lengkap atau menulis penjelasan secara logis, lengkap, namun } \\
\text { tidak benar }\end{array}$ \\
\hline
\end{tabular}

nya. Dari hasil jawaban siswa, dapat diketahui bagaimana kemampuan representasi siswa. Selain itu, dari tes uraian pula peneliti dapat mengelompokkan jawaban sesuai bentuk representasi tertentu. Dokumentasi dilakukan dengan mengabadikan kegiatan berupa pekerjaan siswa, data nama-nama siswa, serta nilai tes kemampuan representasi matematis siswa. Wawancara digunakan untuk mengetahui metode apa yang digunakan siswa, serta mencocokkan antara jawaban dilembar jawab dengan yang sebenarnya dipahami. Wawancara dilaksanakan setelah akhir tes. Instrumen lembar rapresentasi matematis terdiri dari 6 soal dengan rincian seperti pada Tabel 1.

Data yang diperoleh dari penelitian ini berupa skor penilaian hasil jawaban siswa terhadap kemampuan representasi matematis, sehingga diperlukan pedoman dalam menentukan skor dari setiap jawaban siswa tersebut. Pedoman penskoran tersebut digunakan untuk mengukur kempuan representasi matematis siswa. Pedoman penskoran dalam penelitian ini disajikan pada Tabel 2.

Angket yang digunakan pada penelitian ini yaitu berupa lembar angket KLSI (Kolb Learning Style Inventory) yang diadaptasi dari Melinda \&
Wisudawati (2018). Angket ini bertujuan untuk memperoleh data gaya belajar siswa. Instrumen ini memiliki 40 pernyataan dengan 2 pilihan anak kalimat yang harus dirangking mulai dari pilihan 1 sampai 2. Cara penghitungan yang digunakan pada angket ini ialah dengan menghitung jumlah pernyataan dari siswa yang menjawab ya dari keseluruhan pernyataan angket KLSI (Kolb Learning Style Inventory).

Tabel 3. Skoring Instrumen Gaya Belajar David

\begin{tabular}{cc}
\multicolumn{2}{c}{ Kolb } \\
\hline Tipe Gaya Belajar & Jenis \\
\hline Diverger & CE+RO \\
Assimilator & RO+AC \\
Converger & AC+AE \\
Accommodator & AE+CE \\
\hline
\end{tabular}

Keterangan:

$\mathrm{CE}=$ Soal nomor $1-10$

$\mathrm{RO}=$ Soal nomor $11-20$

$\mathrm{AC}=$ Soal nomor $21-30$

$\mathrm{AE}=$ Soal nomor $31-40$

Berdasarkan Tabel 3 dapat ditentukan gaya belajar diverger gabungan antara $\mathrm{CE}$ dan $\mathrm{RO}$, assimilator gabungan antara $\mathrm{AC}$ dan $\mathrm{RO}$, converger gabungan antara $\mathrm{AC}$ dan $\mathrm{AE}$, dan accommodator gabungan antara $\mathrm{CE}$ dan AE. Dengan demikian dapat diambil kesimpulan bagaimana Analisis Gaya Belajar David Kolb menurut Kemampuan Representasi Matematis. 


\section{HASIL DAN PEMBAHASAN}

Data hasil penelitian tes kemampuan representasi matematis siswa secara keseluruhan disajikan dalam Tabel 4 dan Tabel 5.

Tabel 4. Hasil Statistik Deskriptif Kemampuan Representasi Matematis

\begin{tabular}{lc}
\hline \multicolumn{1}{c}{ Statistika } & Hasil \\
\hline Jumlah Sampel (N) & 31 \\
Mean (X) & 66 \\
Median (Me) & 67 \\
Modus (Mo) & 66,6 \\
Varian (S2) & 118.7226 \\
Simpangan Baku (S) & 11,0761 \\
\hline
\end{tabular}

Tabel 5. Hasil Analisis Kemampuan Representasi Matematis

\begin{tabular}{llc}
\hline No. & Kelompok & Jumlah \\
\hline 1. & Tinggi & 3 \\
2. & Sedang & 15 \\
3. & Rendah & 13 \\
\hline & Jumlah & 31 \\
\hline
\end{tabular}

Pengelompokan Tabel 5 digunakan untuk menentukan kemampuan representasi matematis tinggi, sedang dan rendah. Untuk masing-masing siswa akan diberikan angket gaya belajar, lalu diambil 1 sampel dari setiap kelompok sebagai subyek wawancara. Sehingga ada 3 siswa yang menjadi subjek wawancara yang memiliki kemampuan representasi matematis yang berbeda.

Siswa dengan kemampuan representasi matematis tinggi memiliki kecondongan terhadap tipe gaya belajar Assimilator, siswa dengan kemampuan representasi matematis sedang memiliki kecondongan terhadap tipe gaya belajar Converger, sedangkan siswa dengan kemampuan representasi matematis rendah memiliki kecondongan terhadap tipe gaya belajar Diverger.

\section{Gaya Belajar pada Kemampuan Representasi Matematis Tinggi}

Subjek S1 merupakan siswa dengan kemampuan representasi matematis tinggi, dapat terlihat dari hasil dan cara subjek S1 menjawab soal tes representasi matematis. Berikut merupakan uraian indikator gaya belajar David Kolb pada subjek S1.

\section{Belajar Melalui Pemikiran yang Lebih Berfokus pada Analisis Logis Dari Ide- Ide}

Subjek S1 mampu memenuhi indikator yaitu smerupakan pribadi pemikir, disini terlihat dari hasil jawaban angket gaya belajar siswa, subjek S1 memilih jawaban yang kecenderungan kearah berpikir dan memahami, hal ini terlihat jawaban pada poin 11,12 dan 19 di angket gaya belajar siswa. Bahwa siswa merupakan seorang yang memperhatikan dengan cermat dan detail pada semua ujian dan pelajaran, siswa yang diberikan, lebih suka berpikir sebelum mengambi tindakan, dan lebih suka mempertimbangkan sesuatu sebelum mengerjakannya. Ini sesuai dengan tipe gaya belajar assimilator. Tipe gaya belajar assimilator, yang merupakan gabungan antara Abstract Conceptualization (AC) dan Reflective Observation (RO) atau dengan kata lain kombinasi dari pemikiran (thinking) dan pengamatan (watching).

Subjek S1 memenuhi kriteria indikator sebagai siswa dengan tipe gaya belajar assimilator, diperkuat sebagaimana kutipan wawancara dengan subjek S1 yakni sebagai berikut. 
$P \quad$ : Bagaimana cara belajar yang dilakukan oleh anda didalam kelas?

S1 : Berpikir, mendengarkan, menjawab, diskusi, bertanya jika tidak paham.

$P \quad$ : Bagaimana rata-rata hasil dari proses belajar anda?

S1 : Rata-rata hasil proses belajar sangat baik, tidak mengecewakan.

Mengenai wawancara di atas terlihat bahwa subjek S1 merupakan siswa yang sangat menyukai tantangan, dan berpikir sehingga pada poin ke empat menyatakan bahwa rata-rata dari hasil proses belajar dari subjek S1 tidak mengecewakan. Hal ini terlihat dalam pengerjan pada hasil kemampuan representasi matematisnya, subjek S1 menyelesaikan soal dengan jawaban yang benar.

\section{Belajar Melalui Perencanaan Sistematis}

Subjek S1 merupakan siswa yang menyukai hal yang realistis ketika dalam keadaan apapun baik itu ujian maupun berdiskusi. Dalam menyelesaikan pemecahan masalah subjek S1 memiliki ideide praktis untuk menyelesaikannya dan subjek S1 memiliki persiapan yang matang apa saja yang dibutuhkan baik ketika akan ujian maupun berdiskusi. Terlihat pada jawaban angket gaya belajar siswa, pada poin 13, 28 dan 30 . Poin ini memaparkan bahwa subjek merupakan pribadi yang terstruktur, baik dalam menjelaskan maupun mempersiapkan perlengkapan yang akan dipakai dalam menunjang pembelajaran. Seperti hasil dari wawancara berikut.

\footnotetext{
$P \quad$ : Bagaimana kelengkapan sumber belajar anda?

S1 : Untuk kelengkapan belajar saya, saya memakai buku BSE, LKS, dan Internet sebagai pelengkap.
}

Dalam jawabannya subjek memiliki kesiapan dalam menunjang untuk belajar, banyak cara dan perlengkapan yang dipakai yang ditunjukkan pada Gambar 1.

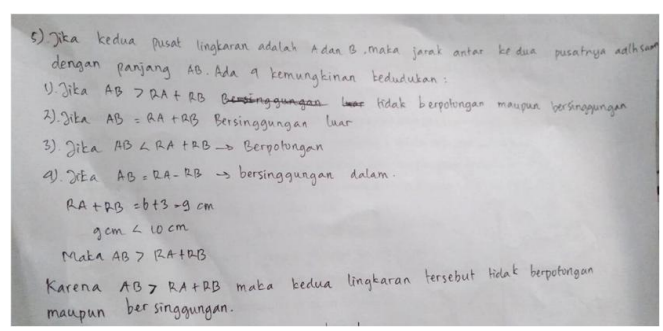

Gambar 1. Jawaban Tes Representasi Siswa S1

Dalam pemaparan di atas terlihat sekali dalam menjelaskan jawaban, siswa menjelaskannya dengan terstruktur pula. Jawaban diatas merupakan jawaban yang diinginkan oleh peneliti. Di sini menjelaskan bahwa subjek merupakan pribadi dengan perencana yang sistematis. Sehingga dapat disimpulkan bahwa subjek S1 merupakan siswa yang memiliki perencanaan yang sistematis.

\section{Belajar Melalui Pengamatan}

Subjek S1 merupakan siswa yang sangat memperhatikan dengan cermat dan detail mengenai hasil dan pelajaran yang didapatkan. Hal ini sesuai dengan poin $11,15,18$, dan 19 di angket gaya belajar siswa. Subjek S1 lebih banyak bertindak pasif dibandingkan aktif baik ketika dalam keadaan belajar maupun berdiskusi.

S1 belajar dengan melakukan segala sesuatu dipikir terlebih dahulu sebelum dikejakan sehingga tidak adanya kesalahan dalam melakukan pembelajaran. Terlihat dalam pengerjaan hasil kemampuan representasi matematisnya, subjek S1 mendapatkan nilai yang sangat 
baik. Untuk pengerjaan persoal subjek S1 memberikan jawaban-jawaban yang begitu detail, meskipun ada beberapa jawaban yang diberikan belum memenuhi kriteria jawaban yang benar, namun subjek S1 sudah memenuhi standar siswa yang memiliki kemampuan representsi matematis tinggi.

\section{Belajar Melalui Mengamati Suatu Perkara dari Berbagai Perspektif}

Subjek S1 merupakan siswa dengan tipe yang melahap bahan bacaan dari berbagai sumber, baik cetak maupun digital, guna memecahkan masalah yang berkaitan dengan matematika maupun pelajaran lainnya. Hal ini sesuia dengan poin 14,15 , dan 16 angket gaya belajar subjek.

Subjek S1 juga merupakan tipe pendengar yang baik, karena dia merupakan siswa yang suka mendengarkan dibandingkan berbicara. Terlihat dari poin 19 dan 22 angket gaya belajar subjek.

Setelah menelaah beberapa indikator-indikator dari hasil tes gaya belajar diatas dapat disimpulkan bahwa subjek S1, siswa dengan kemampuan representasi matematis tinggi memiliki gaya belajar Assimilator. Penelitian ini didukung oleh penelitian yang telah dilakukan oleh Melinda \& Wisudawati, (2018) bahwa dalam penelitiannya siswa berprestasi memiliki tipe gaya belajar assimilator terbanyak.

\section{Gaya Belajar pada Kemampuan Representasi Matematis Sedang}

Subjek S2 merupakan salah satu siswa yang memiliki nilai representasi matematis sedang. Subjek S2 memiliki kecenderungan terhadap gaya belajar converger. Terlihat dari hasil jawaban siswa dan didukung oleh wawancara terhadap subjek S2. Bahwa subjek S2 merupakan siswa yang memiliki pemahaman dan pemikiran yang baik dalam pelajaran maupun pemecahan masalah dalam kehidupan sehari-hari.

Tipe ini perpaduan antara Abstract Conceptualization (AC) dan Active Experimentation (AE) atau dengan kata lain kombinasi dari berpikir (thinking) dan berbuat (doing). Hasil analisis tipe gaya belajar converger pada kemampuan representasi matematis sedang diperoleh fakta bahwa secara umum siswa telah mencakup indikator-indikator tipe gaya belajar converger.

Hal ini didukung dengan penelitian yang dilakukan oleh Daimaturrohmatin \& Rufiana, (2019) menyatakan bahwa siswa dengan tipe gaya belajar converger lebih dominan menguasai seluruh indikator kemampuan komunikasi matematis yang telah ditentukan.

Berikut ini merupakan penyajian data berdasarkan indikator analisis gaya belajar David Kolb.

\section{Belajar Melalui Pemikiran yang Lebih Berfokus pada Analisis Logis dari Ide- Ide}

Subjek S2 merupakan siswa yang ketika berdiskusi suka membahas langsung ke inti topik yang didiskusikan. Siswa gemar belajar bila menghadapi soal dengan jawaban yang pasti, dan segera berusaha mencari jawaban yang tepat. Hal ini sesuai dengan poin 21, 22, 24, dan 27 dari angket gaya belajar subjek. Subjek S2 merupakan siswa dengan pemikiran yang logis. Wawan- 
cara dengan subjek S2 juga mendukung mengenai pernyataan tersebut.

$P \quad$ : Bagaimana rata-rata hasil dari proses belajar anda?

S2 : Nilai hasil rata-rata belajar saya lumayan bagus, untuk pembelajaran matematika tengah-tengah tidak terlalu baik dan tidak terlalu buruk. Namun, untuk pelajaran lain seperti science nilai saya dominan bagus.

$P \quad:$ Apakah anda sering memecahkan masalah dengan menggunakan logika?

S2 : Ya, karena saya sangat suka dengan sesuatu yang logis.

Terlihat dalam menjawab pertanyaan dari peneliti bahwa subjek S2 merupakan siswa yang realistic tidak suka dengan hal yang bertele-tele.

\section{Belajar Melalui Perencanaan Sistematis}

Subjek S2 merupakan siswa yang mampu merespons terhadap berbagai peluang dan mampu bekerja secara aktif dalam setiap tugas yang terdefinisikan secara baik. Dia mau belajar secara trial and error hanya dalam lingkungan yang dianggapnya relatif aman dari kegagalan. Selain itu juga subjek S2 juga memiliki ide-ide yang praktis dalam menyelesaikan pemecahan masalah yang terjadi. Hal ini terlihat pada poin 33,34 , dan 36 angket gaya belajar subjek dan didukung oleh pernyataan subjek dalam wawancara berikut ini.

$P \quad$ : Apa yang anda lakukan jika menemukan kesulitan dalam mengerjakan tugas yang berkaitan dengan matematika?

S2 : Bagaimana caranya saya harus mencari solusimya terlebih dahulu, dan saya sangat suka bertanya atau berdiskusi dengan teman atau guru.

$P \quad$ : Bagaimana cara belajar yang dilakukan oleh anda didalam kelas?

S2 : Mendengarkan, menulis, menjawab, bertanya dan berdiskusi.
Belajar Melalui Tindakan Yaitu Melaksanakan, Berani Mengambil Resiko, dan Mempengaruhi Orang Lewat Perbuatannya

Subjek S2 adalah siswa yang gemar mengerjakan PR matematika, dan menjawab pertanyaan yang diberikan oleh guru dengan respon yang spontan. Subjek S2 merupakan pribadi yang aktif, menyukai segala tantangan baru, dan ketika mengerjakan soal-soal yang diberikan guru subjek S2 menyelesaikan soal dengan berbagai cara yang baru. Dan ketika ada teman yang kesusahan dalam mengerjakan soal, subjek S2 merupakan tipe pribadi yang tidak segan untuk membantu dan subjek S2 juga merupakan pribadi yang senang berbicara, ketika berdiskusi subjek S2 berperan penuh sebagai siswa yang aktif berbicara. Selain aktif di dalam berdiskusi subjek S2 juga merupakan siswa yang aktif mengajak teman- temannya untuk belajar bersama. Hal ini dengan poin 37 dan 38 angket gaya belajar subjek. Menunjukkan bahwa subjek S2 memenuhi kriteria indikator sebagai siswa dengan tipe gaya belajar converger, sebagaimana ringkasan wawancara dengan subjek S2 yakni sebagai berikut.

$P \quad$ : Bagaimana cara anda berpikir dalam memecahkan sebuah persoalan dengan matematika?

S2 : Kita harus mengetahui permasalahannya terlebih dahulu apa yang ditanya dan apa yang harus di jawab. Lalu mencari solusi dengan apa yang ada kaitannya dengan matematika. Dengan mencari materi yang pas untuk permasalahan tersebut.

$P \quad$ : Cara apa yang anda lakukan dalam mempengaruhi orang lain?

S2 : Memberikan dia sesuatu yang sedang dibutukannya. Lalu memberikan kepercayaan dengan mempengaruhi dia bahwa yang akan saya ajak ini mengarah kepada kebaikan. 
Setelah menelaah lebih lanjut mengenai ketuntasan indikator sehingga dapat disimpulkan bahwa siswa dengan kemampuan representasi sedang yaitu subjek S2 merupakan siswa dengan tipe gaya belajar converger. Penelitian ini didukung oleh penelitian yang telah dilakukan oleh Rofiqoh, (2015) menyatakan bahwa gaya belajar converger paling banyak jumlah nya di kelas X.

\section{Gaya Belajar pada Kemampuan Representasi Matematis Rendah}

Subjek S3 merupakan salah satu siswa yang memiliki hasil nilai dengan kemampuan representasi matematis rendah. Seperti ujian yang telah diberikan oleh peneliti kepada siswa. Subjek S3 masih belum mampu memecahkan soal matematis, terlihat dari jawaban-jawaban yang dituangkan olehnya. Masih banyak jawaban yang tidak selesai dan beberapa jawaban kosong. Keadaan seperti inilah membuat peneliti penasaran terhadap subjek, tipe gaya belajar apakah yang dimiliki oleh siswa sehingga setelah didapatkan hasil dari tes kemampuan representasi matematis, peneliti memberikan beberapa soal tes gaya belajar kepada siswa untuk mengetahui gaya belajar apakah yang dimiliki oleh siswa. Tipe ini perpaduan antara Concrete Experience (CE) dan Reflective Observation (RO), atau dengan kata lain kombinasi dari perasaan (feeling) dan

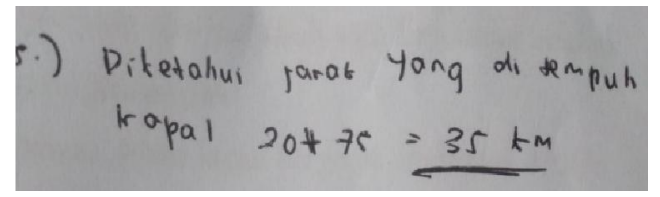

Gambar 2. Jawaban Tes Representasi Siswa S3 pengamatan (watching). Berikut ini merupakan penyajian data berdasarkan indikator analisis gaya belajar David Kolb.

\section{Belajar Melalui Perasaan dengan Menekankan Segi Pengalaman Konkrit}

Subjek S3 merupakan siswa yang ketika belajar menggunakan perasaan dan keyakinan yang kuat bahwa apa yang telah didapatkan sangat bermanfaat dan berguna bagi kehidupannya. Subjek S3 juga memiliki keyakinan bahwa dia mampu memecahkan masalah dalam pembelajaran dengan urut dan benar. Hal ini telihat pada poin 1 dan 2 angket gaya belajar subjek.

Terlihat sekali bahwa subjek S3 merupakan tipe yang menekankan pengalaman konkrit menggunakan perasaan. Subjek S3 memiliki keyakinan bahwa subjek mampu memecahkan masalah. Meskipun secara kenyataannya masih banyak terjadi kesalahan yang dikerjakan oleh subjek. Hal tersebut dapat terlihat di dalam pengerjaannya mengerjakan soal kemampuan representasi matematis. Banyak jawaban yang salah dalam mengungkapkannya. Sehingga subjek S3 mendapatkan nilai kemampuan representasi matematis rendah. Berikut Gambar 2 merupakan jawaban dari subjek S3 dalam soal kemampuan representasi matematis.

Gambar 2 merupakan jawaban subjek S3 pada soal kemampuan representasi matematis no.6, penulis meminta subjek dapat menjelaskan pemecahan masalah dari soal cerita matematis, namun subjek kurang dapat memahami dan belum bisa menemukan solusi dari soal representasi matematis di 
atas. Namun, subjek S3, memiliki keyakinan atas dirinya bahwa subjek mampu menyelesaikannnya dengan baik.

Berikut merupakan wawancara terhadap subjek S3 yang mendukung poin di atas.

\section{$P \quad:$ Hal yang anda rasakan saat menyelesaikan masalah yang berkaitan dengan matematika?}

S3 : Saya bisa menyelesaikan masalah yang berkaitan dengan matematika, namun tekadang saya merasa bingung, dan stres jika soal tersebut terlalu sulit.

Pernyataan tersebut menunjukkan bahwa subjek merupakan seseorang yang menekankan segala pengalaman konkrit menggunakan perasaannya.

\section{Belajar Melalui Perasaan dengan Menekankan Segi Relasi dengan Sesama}

Subjek S3 merupakan siswa yang aktif bertanya kepada guru mengenai materi-materi yang tidak dikuasai. Subjek S3 memiliki kemauan yang tumbuh didalam dirinya untuk belajar tanpa ada rasa malu maupun segan. Sesuai dengan poin nomor 6 angket gaya belajar subjek. Berikut wawancara dengan subjek S3.

\footnotetext{
$P \quad$ : Apa yang anda lakukan jika menemukan kesulitan dalam mengerjakan tugas yang berkaitan dengan matematika?

S3 : Saya tinggal tidur, nanti saya tanya keteman atau mencontek pekerjaan mereka.
}

Pernyataan tersebut menjelaskan bahwa subjek tipe siswa yang belajar dengan mementingkan segi relasinya.
Belajar Melalui Perasaan dengan Menekankan Segi Sensitivitas terhadap Perasaan Orang Lain

Subjek S3 merupakan siswa yang bertindak tanpa memikirkan konsekuensi, merespon secara spontan dan siswa yang tidak suka jika ada teman ketika berdiskusi menyimpang dari apa yang sedang didiskusikan. Hal tersebut merupakan poin 29,33 , dan 35 .

Setelah ditelaah lebih lanjut mengenai tipe gaya belajar, dengan hasil tes dan wawancara terhadap subjek didapatkan hasil bahwa siswa S3 merupakan siswa yang memiliki kecondongan terhadap tipe gaya belajar diverger. Kutipan wawancara dengan subjek S3 yakni sebagai berikut.

$P \quad$ : Bagaimana perasaan anda dalam menyikapi suatu perubahan dalam pengalaman hidup?

S3 : Perasaan senang ketika perubahan itu semakin membaik, namun jika perubahan itu semakin memburuk maka perasaan khawatir dan cemas yang saya hadapi.

$P \quad$ : Bagaimana rata-rata hasil dari proses belajar anda?

S3 : Rata-rata hasil dari proses belajar saya untuk bidang matematika tidak terlalu bagus. Terkadang saya medapatkan nilai di bawah rata-rata. 
Tabel 6. Indikator Gaya Belajar David Kolb Berdasarkan Kemampuan Representasi Matematis

\begin{tabular}{|c|c|}
\hline $\begin{array}{c}\text { Kemampuan Representasi } \\
\text { Matematis }\end{array}$ & Indikator Gaya Belajar David Kolb \\
\hline Tinggi & $\begin{array}{l}\text { 1. Belajar melalui pemikiran yang lebih berfokus pada analisis logis dari } \\
\text { ide-ide. } \\
\text { 2. Belajar melalui perencanaan sistematisc. } \\
\text { 3. Belajar Melalui Pengamatan } \\
\text { 4. Belajar melalui mengamati suatu perkara dari berbagai perspektif. }\end{array}$ \\
\hline Sedang & $\begin{array}{l}\text { 1. Belajar melalui pemikiran yang lebih berfokus pada analisis logis dari } \\
\text { ide-ide. } \\
\text { 2. Belajar melalui perencanaan sistematisc } \\
\text { 3. Belajar melalui tindakan yaitu melaksanakan, berani mengambil resiko } \\
\text { dan mempengaruhi orang lewat perbuatannya. }\end{array}$ \\
\hline Rendah & $\begin{array}{l}\text { 1. Belajar melalui tindakan yaitu melaksanakan, berani mengambil resiko } \\
\text { dan mempengaruhi orang lewat perbuatannya. } \\
\text { 2. Belajar melalui perasaan dengan menekankan segi relasi dengan } \\
\text { sesama. } \\
\text { 3. Belajar melalui perasaan dengan menekankan segi sensitivitas terhadap } \\
\text { perasaan orang lain. }\end{array}$ \\
\hline
\end{tabular}

Setelah menelaah beberapa indikator-indikator dari hasil tes gaya belajar di atas dapat disimpulkan bahwa subjek S3, merupakan siswa dengan kemampuan representasi matematis rendah yang memiliki gaya belajar diverger terbanyak. Hasil penelitian ini didukung dengan penelitian Azrai et al., (2018) menyatakan bahwa gaya belajar siswa SMAN 105 Jakarta tersebar dalam 4 ragam gaya yaitu diverger, assimilator, akomodator, dan konverger. Kelompok siswa dengan gaya belajar terbesar adalah diverger diikuti gaya belajar assimilator, accommodator dan converger. Terdapat perbedaan sebaran gaya belajar pada masing-masing tingkatan kelas. Hal ini didukung oleh penelitian yang telah dilakukan oleh Sukmana, (2017) bahwa tipe gaya belajar diverger merupakan tipe gaya belajar terbanyak di kelas mencapai 39\%.

Berdasarkan penyajian data pada tiap indikator gaya belajar David Kolb menurut kemampuan representasi matematisnya, penarikan kesimpulan yang peneliti lakukan dapat dilihat selengkapnya pada Tabel 6 .

\section{PENUTUP}

Berdasarkan penelitian ini, diperoleh kesimpulan sebagai berikut. Ada tiga kemampuan representasi matematis yang menjadi tolak ukur di penelitian ini, yakni: kemampuan representasi matematis tinggi, kemampuan representasi matematis sedang, dan kemampuan representasi matematis rendah.

Siswa dengan kemampuan representasi tinggi cenderung memiliki tipe gaya belajar assimilator, tipe gaya belajar assimilator merupakan tipe gaya belajar perpaduan antara Abstract Conceptualization (AC) dan Reflective Observation (RO) atau kombinasi dari pemikiran (thinking) dan pengamatan (watching). Siswa dengan tipe Assimilator memiliki keunggulan dalam memahami dan merespons berbagai sajian informasi serta mengorganisasikan merangkumkannya dalam suatu format yang logis, singkat, dan jelas. Siswa tipe ini cenderung lebih teoritis, lebih menyukai bekerja dengan ide serta konsep yang abstrak, daripada bekerja dengan orang. 
Siswa dengan kemampuan representasi sedang cenderung memiliki tipe gaya belajar converger. Tipe ini perpaduan antara Abstract Conceptualization (AC) dan Active Experimentation (AE) atau dengan kata lain kombinasi dari berpikir (thinking) dan berbuat (doing). Siswa mampu merespons terhadap berbagai peluang dan mampu bekerja secara aktif dalam setiap tugas yang terdefinisikan secara baik. Siswa gemar belajar bila menghadapi soal dengan jawaban yang pasti, dan segera berusaha mencari jawaban yang tepat. Dia mau belajar secara trial and error hanya dalam lingkungan yang dianggapnya relatif aman dari kegagalan. Siswa dengan tipe Converger unggul dalam menemukan fungsi praktis dari berbagai ide dan teori. Biasanya mereka punya kemampuan yang baik dalam pemecahan masalah dan pengambilan keputusan. Mereka juga cenderung lebih menyukai tugas-tugas teknis (aplikatif). Dia cenderung tidak emosional dan lebih menyukai bekerja yang berhubungan dengan benda dari pada manusia, masalah sosial atau hubungan antar pribadi.

Siswa dengan kemampuan representasi rendah cenderung memiliki tipe gaya belajar diverger. Tipe gaya belajar diverger merupkan perpaduan antara Concrete Experience (CE) dan Reflective Observation (RO), atau dengan kata lain kombinasi dari perasaan (feeling) dan pengamatan (watching). Siswa dengan tipe Diverger memiliki keunggulan dalam kemampuan imajinasi dan melihat situasi kongkret dari banyak sudut pandang yang berbeda, kemudian menghubungkannya menjadi sesuatu yang bulat dan utuh. Pendekatannya pada setiap situasi adalah "mengamati" dan bukan "bertindak". Siswa seperti ini menyukai tugas belajar yang menuntutnya untuk menghasilkan ide-ide dan gemar mengumpulkan berbagai informasi, menyukai isu tentang kesusastraan, budaya, sejarah, dan ilmuilmu sosial lainnya.

Berdasarkan hasil penelitian ini, Guru matematika perlu mengidentifikasi gaya belajar yang dimiliki oleh siswa. Untuk mengetahui karakteristik dari setiap siswa. Dengan tujuan agar mampu berperan sebagai guru yang sesuai dengan karakteristik siswa. Direkomendasikan pula pembendaharaan soal berbasis representasi matematis dapat dilakukan oleh guru matematika dalam upaya meningkatkan kemampuan representasi matematis siswa.

Penelitian ini hanya mendeskripsikan gaya belajar David Kolb menuruut kemampuan representasi matematis siswa dan belum dilakukan kajian terhadap hal-hal penting lainnya seperti hubungan masing-masing gaya belajar David Kolb terhadap aktivias-aktivitas dalam kemampuan representasi matematis, sehingga perlu, dilakukan penelitian yang lebih mendalam.

\section{DAFTAR PUSTAKA}

Azrai, E. P., Ernawati, E., \& Sulistianingrum, G. (2018). Ragam Gaya Belajar Siswa SMA Menurut David Kolb dalam Pembelajaran Biologi. Jurnal Al-Azhar Indonesia Seri Humaniora, 4(4), 251-255.

Daimaturrohmatin, D., \& Rufiana, I. S. (2019). Analisis Kemampuan Komunikasi Matematis Siswa Ditinjau dari Gaya Belajar Kolb. EDUPEDIA, 3(1), 17-31. 
Hudojo, H. (2002). Representasi Berbasis Masalah. Makalah Disampaikan Pada Konferensi Nasional Matematika XI. Universitas Negeri Malang. Malang, 22-25.

Keefe, J. W. (1979). Learning style: An overview. Student Learning Styles: Diagnosing and Prescribing Programs, 1(1), 1-17.

Kolb, A. Y., \& Kolb, D. A. (2005). Learning Styles and Learning Spaces: Enhancing Experiential Learning in Higher Education. Academy of Management Learning \& Education, 4(2), 193-212.

Kolb, D. (1984). Experienatlal learning. Prentice-Hall, Englewood Cliffs, NJ.

Martin, W. G. (2000). Principles and standards for school mathematics (Vol. 1). National Council of Teachers of.

Melinda, D., \& Wisudawati, A. W. (2018). Identifikasi Gaya Belajar Model Kolb Terhadap Peserta Didik MAN II Yogyakarta. Jurnal Pendidikan Sains (Jps), 6(1), 47.

Murfi, A., \& Rosidah, N. S. (2016). Analisis Gaya Belajar Siswa Berprestasi Studi Komparasi Siswa Berprestasi SMAN 1 dengan MAN 1 Yogyakarta Kelas XI. Jurnal Pendidikan Madrasah, 1(2), 295308.

Nasution, S. (2000). Berbagai pendekatan dalam proses belajar dan mengajar.

Nur, M. G., \& Risnawita, R. (2014). Gaya Belajar Kajian Teoritik. Yogyakarta: Pustaka Pelajar.

Rofiqoh, Z. (2015). Analisis Kemampuan Pemecahan Masalah Matematika Siswa Kelas X Dalam
Pembelajaran Discovery Learning Berdasarkan Gaya Belajar Siswa.

Santosa, M. C. (2017). Deskripsi Kemampuan Representasi Matematis Ditinjau Dari Gaya Belajar Siswa Kelas Viii Smp Negeri 1 Kembaran [Phd Thesis]. Universitas Muhammadiyah Purwokerto.

Suharyanto, S. (1998). Pengembangan Model Pengajaran Fisika Berbantuan Komputer. Jurnal Kependidikan: Penelitian Inovasi Pembelajaran, 28(1), 77-88.

Sukmana, S. H. (2017). Analisa Kecenderungan Dan Jenis Gaya Belajar Menggunakan Metode Learning Style Inventory (Lsi). Jurnal Pilar Nusa Mandiri, 13(2), 175-180.

Syah, M. (2016). Psikologi Pendidikan (Bandung). PT. Remaja Rosakarya. //repo.unikadelasalle.ac.id\%2Finde x.php $\% 3 \mathrm{Fp} \% 3$ Dshow_detail\%26id $\% 3 \mathrm{D} 11142 \% 26$ keywords\%3D 